\title{
ANALYSIS OF THE BULGARIAN EXPERIENCE IN THE DEVELOPMENT OF THE SOCIAL ADAPTATION OF SERVICEMEN, DISCHARGED FROM MILITARY SERVICE
}

\author{
Venelin Terziev \\ Academician of the Russian Academy of Natural History, Moscow, Russia, Prof. \\ D.Sc. (Ec.), D.Sc. (National Security), D.Sc. (Social Activities), Ph.D., National Military University, \\ Veliko Tarnovo, Bulgaria; University of Rousse, Rousse, Bulgaria, terziev@skmat.com
}

\begin{abstract}
Tracing the practice up to now, it is noteworthy that the attention of all organizations and institutions concerned with social adaptation of servicemen, discharged from military service, in the initial period of the 90s of last century, when in the structures of the Ministry of Defense drastic reforms were carried out, accompanied by a reduction of the staff,was initially focused only on goals for organization of the re-training (re-qualification) and job settling of servicemen, passing in the reserve. This is confirmedby the very legislation, as far as such can be considered existing in this period. The very names of the various documents suggest that at this stage the task of a comprehensive approach to solving the problem was not set. The specialist in given area, at the beginning of their activity believe, that the opprtunity of passing retraining in civil specialty allows the discharged from military service serviceman to getdecent work in civil life.
\end{abstract}

Keywords: analysis, development, adaptation.

\section{INTRODUCTION}

Tracing the practice up to now, it is noteworthy that the attention of all organizations and institutions concerned with social adaptation of servicemen, discharged from military service, in the initial period of the 90s of last century, when in the structures of the Ministry of Defense drastic reforms were carried out, accompanied by a reduction of the staff,was initially focused only on goals for organization of the re-training (re-qualification) and job settling of servicemen, passing in the reserve. This is confirmedby the very legislation, as far as such can be considered existing in this period. The very names of the various documents suggest that at this stage the task of a comprehensive approach to solving the problem was not set. The specialist in given area, at the beginning of their activity believe, that the opprtunity of passing retraining in civil specialty allows the discharged from military service serviceman to getdecent work in civil life.

More specifically, the main directions in the work at this first stage were:

- Organization of educational institutions of different types (from training centers and courses, to various 
institutes, for implementation of the conversion);

- Formation of normative-legal basis for the organization of this conversion;

- Seeking and creating new jobs;

- Creatingakind of „military“ employment bureaus- specific offices for job finding, for the servicemen, discharged from military service;

- Formation of bodies for coordination of the system for conversion and finding jobsforservicemen, discharged from military service;

- Creation of material and technical organizational conditions for the functioning of this system, etc.

A top priority of the formed conversion system is the conversion of the servicemen, discharged from military service, into civilian professions. A methodological basis for choosing this priority is a postulate that having a new profession ensures the social adaptation to civilian lifeof the serviceman, passing in the reserve.

The number of discharged servicemen in certain periods, caused by the restructuring of the Bulgarian army continues to grow, while the number of vacancies in the public sector falls sharply. As a result, there are problems, which in previous years need no special intervention. Arises the need for greater consideration of the process of social adaptation of discharged servicemen, as well as of working with their family members.

Experience has shown that the discharged from military service servicemen successfully deal with exercising entrepreneurship and realizing other regional social and economic projects. The creation of a system of professional guidance, re-qualification, job finding and social adaptation, is necessary, also with regard to the absolutely unjustified mass filling at the expense of the potentially active part of the population, of the alreadyunacceptablygreat share of the people on sustentation. Moreover that it is recognized as appropriate to create favorable conditions for the acceleration of the adaptation of servicemen,passing in the reserve, and members of their families to civilian life, allowing them to become one of the active and economically independent categories of the population.

Unfortunately, the formation of this system is accompanied by lagging back of the organizational arrangements without the mandatory foresight, often as a late response to the problem without serious coordination efforts of the involvedorganizations, institutions and individuals. The formed system is too controversial. It does not bear a complex nature and has incorrectly selected priorities, resulting in an accumulation of a series of errors, reduction of the effect of the taken measures and significant increase of the cost of the process of social adaptation with regard to the individual serviceman.

As a result of this activity in Bulgaria operate three relatively independent and competing systems for requalification of servicemen, discharged from military service. The first is the state system. It includes educational institutions of higher education, engaged in education and retraining (re-qualification) in civil specialties of individuals, including servicemen, discharged from military service, licensed by the National Agency for Vocational Education and Training. An important trend in the development of this system is the education of the servicemen in the higher military schools, which ends with a diploma in one of the civil specialties. Basis for such a decision becomes the allegation that a second civil degree for the young officer raises the level of his social protection.

Fallacy of this approach was proved by the practice in recent years. It comes to the following:

First, civil specialty obtained by the young officer in the military high school, corresponds to the accepted professional standard only at the time of graduating from high school. Performing for many years his duties in the main (military) specialty, the officer practically is deskilling in the civil sphere (with the exception of general technical, engineering, medical, financial, economic and other professions). As a result, after the discharge from the army, the level of his professional competence in the civil sphere is so low that to find a job in accordance with the diploma obtained ten years ago, is almost impossible.

Second, the results show that the narrow professional specialization acquired by the majority of servicemen during service is often unnecessary in civilian conditions. Moreover, the low load of the production capacity of enterprises on a mass scale, and reduction of management personnel, lead to a glut of the labor market with skilled workforce, in which the discharged serviceman feels quite "uncomfortable". The most common offers for military reservists, as a rule, are the positions of guard, freight forwarder, collector, etc.. At that, employers are not at all interested in the holding of a degree or mastering a special knowledge by their future employee.

Third, studies have shown that the degree of compliance of the new types and content of work of the 
discharged from military service servicemen, of the level of their education and training acquired during military service, is quite low.

Fourth, the acquisition by young officers of civil specialties in the higher military schools objectively contributes to leaving the Bulgarian army, which greatly weakens the military body of the country and leads to the unwarranted spending of resources.

The specifics of military service often do not allow the family members of servicemen to work in the places of their residence, especially on their primary specialty. After discharge from military service and determining the permanent residence, members of servicemen's family have also lost their professional competence and turn out to be in an uncompetitive situation in the labor market, compared to their peers from civil society. This fact necessitates the inclusion of family members of military staff in the system of re-qualification for new professions or increase of their qualifications.

Analyzing the work of civil educationinstitutions, including vocational training centers in the field of conversion of servicemen, passing in the reserve, and the members of their families (primarily with a view to their further job placement in the new conditions of life), it can be concluded that this activity is not primary for the civil universities, and therefore it is paid significantly less attention than necessary. In the market conditions, for the re-qualification of military servicemen, civilian universities require additional financing, which is quite burdensome for the state in the existing budget deficit.

From the state system for retraining of servicemen, passing in the reserve, and members of their families, drop those categories that are forced (due to lack of other housing) to live in closed or remote from large cities settlements. These servicemen have no opportunity to undertake retraining in respective universities or vocational training centers. Furthermore, this system for retraining of servicemen, passing in the reserve, and members of their families, is not oriented towards solving the problem of finding a job. As a result, its effectiveness is negligible. Thus the state system for conversion of military personnel is generally not able to independently solve the task for professional re-orientation, conversion (re-qualification) and job placement of servicemen, passing in the reserve and members of their families, on civil jobs.

Nowadays, these tasks also cannot be solved independently by the state system in a functioning market economy. The shortcomings of the state system's conversion (re-qualification) of the servicemen, objectively lead to the formation of another principallydifferent system - nongovernmental,off-budgetary one. It is oriented towards the solution of these tasks at the expense of attracting funds from European programs for the development of human resources, from targeted funding of qualification and re-qualification of staff from among the discharged from military service servicemen, from private and foreign organizations, from individual payment of the requalified military reservists, and members of their families, and others. In many cases, the system uses the funds provided for in the National Action Plan for Action on Employment of the Ministry of Labor and Social Policy.

The creation of extra-budgetary system benefits from the loss of state monopoly on education and employment of people, including the military reservists, as well as from the limitations of these options in the budget system. Competition between them contributes to the forming of the offbudgetary system for requalification of servicemen, passing in the reserve, initially as complementary to the state (budget) system and for a number of positions also as an alternative to it. This system allows for the more flexible and operationalresponse to changes in the labor market and labor force. In view of mutual interest to establish relations of the discharged from military service servicemen with employers, the goal is to provide requalification of servicemen, discharged from military service in professions, providing them with guaranteed job. It is the offbudgetarysystem conversion (re-qualification) of servicemen and members of their families, whichbecame the initiator of the idea of merging the problems of professional orientation, requalification and job placement in a single system for social adaptation to the conditions of civil life. This idea nowadays acquires the status of a generally accepted point of view. However, in Bulgaria there is no national strategy or plan for the process of social adaptation.

The off-budgetary system includes a number of educational and training institutions, such as independent legal entities, seeking to spread its influence primarily on potentially vulnerable groups of unemployed people, including that of the discharged servicemen, using also the forms of remote learning. It also includes organizing employment bureaus and other similar initiatives. In many cases, the activities of the various institutions of the off-budgetary system is directed to the creation of new jobs, taking in consideration the specifics of local and regional needs and existing potential.

Among the shortcomings of the system under consideration,the most significant are:

- Deficiency of material-financial and organizational-technical means for organizing its activities; 
- Fragmented nature of the functioning of the various sub-systems and institutions;

- Deficiency of professionally trained personnel of the organizers of the educational process in educational institutions and systems;

- Lack of strategy for its development and bodies capable of providing coordination of all the work within the country;

- Contradictions in relations with the budgetary system and state structures;

- Underdevelopment of the normative-legal basis for the operation of the system;

- Weakness of its information-analytical and prognostic provision;

- Errors in setting the priorities in the selection of professions for qualification in, etc.

Nevertheless, the off-budgetary system for conversion (re-qualification) of the servicemen, discharged from military service, which nowadays is developing into a system for their professional orientation, training and job placement, complementing the budgetary (state) system, allows to significantly expand the potential opportunities for obtaining new civil professions by the servicemen, discharged from military service and members of their families, and jobs in accordance with them. Thus, this system makes a considerable contribution to solving the problems of social adaptation of servicemen, discharged from military service to the new conditions of life, and to lessening the social tension among them and among these servicemen who are about to be discharged from military service. However, as a separate option it also is not able to solve the complex problems associated with the reduction of the Bulgarian Army.

In parallel with the formation of budgetary and off-budgetary systems for qualification and job placement of the servicemen, discharged from military service, and members of their families, a third systemis also formed - the investment system. Its features are:

- Release of funds from various organizations and funds;

- Program-targeted financing of re-qualification and job placement of the servicemen;

- Giving priority to economic and market-oriented professions in the conversion of the servicemen, passing in the reserve;

- Limiting the deadlines for their conversion to several months;

- Attraction of foreign experts from different profile for the realization of the goals and objectives of this system;

- Choice-based orientation of the interaction with the budgetary and off-budgetary systems, etc.

The last feature of the investment system is a key to the further development of the common system of vocational guidance, conversion (re-qualification) and job placement of the servicemen, discharged from military service, and members of their families in Bulgaria.

The formation of the system for social adaptation of military reservists and their family members, which primarily means their re-qualification for new professions, is accompanied by the development of its infrastructure (training centers, etc.), based in principle on the potential of universities of the Ministry of Education and Science. On the one hand, the universities are located in cities, which automatically restricts access to re-qualification for the majority of the discharged servicemen and the members of their families, who are permanently residing in areas away from the university centers. On the other hand, there are various administrative obstacles and flaws in the coordination of this specific activity.

The brief retrospective review of the development of social work with the discharged from military service servicemen and their families, with pointing out the contradictions, disadvantages, difficulties and mistakes in its development, allows to derive the trends - positive and negative, in the development of the social adaptation.

Among the positive trends, attention deserve:

- Compensation of the insufficiency of funds by funding under European programs;

- Accumulation of experience by various government structures for solving these problems;

- Involving different institutions (Ministry of Labor and Social Policy, Ministry of Education and Science, Ministry of Defence, the Social Assistance Agency and its territorial divisions, the Agency on Employment 
and its territorial divisions, etc.) to the work on social adaptation of discharged military servicemen and members of their families;

- Creating specialized organizational structures or units, solving the problems of this category of the population (the formed risk groups in the labor market, such as the ex-servicemen),etc.

The negative trends of development of this system are:

- Predominant orientation of the state institutions to the retraining of discharged from military service servicemen and members of their families and limiting the process of their social adaptation to requalificationand partly job placement;

- Lack of coordination on the part of the government institutions with the activities of other organizations dealing with the problems of social adaptation of military reservists, including public and non-governmental organizations;

- Unresolved so far inter-institutional conflicts;

- High dependence of the activitiesfor social adaptation of the mentioned category on the population and on the amount of funding (determined by the budgetary framework of the National Action Plan for Employment);

- Lack of qualified staff for managing the processes of social adaptation of discharged from military service servicemen and members of their families, etc.

All these circumstances demand the development of a concept and model of social adaptation of this category of the population with a view to the best experience from the activities of individual organizations in the country, the positive foreign experience, and the results of their own experience and expertise work.

Although within the frame of conversion (re-qualification) of the discharged from military service servicemen and members of their families, other tasks of their social adaptation are also solved, they are not set directly, although sometimes denoted. Autonomous solvingof these tasks does not provide the necessary result of reintegration of this category of the population in the civil socium. This is confirmed by the analysis of the practical realization of social adaptation of servicemen, discharged from military service.

\section{STIMULATION OF SOCIAL ADAPTATION OF THE DISCHARGED FROM MILITARY SERVICE IN THE CIVIL SOCIETY}

In the years of preparation for accession of the country and the MF, to NATO, attention shall be paid by the Ministry of Defense to the not easy task, provoked by the processes of reformation and reduction in the military structures, how to stimulate the social adaptation of discharged from military service servicemen. In this regard, between the Ministry of Defence $(\mathrm{MoD})$ and the Ministry of Labor and Social Policy an agreement for this activity was concluded. MoD approved an ordinance on the basis of which the Chief of Staff issued a decree on recruiting officers as civil staff in all units of the BA. These are the people who contact between military centers for motivational courses and military clubs. This builds a broad network that conducts motivational courses preceding courses for training and retraining. Information on vacancies is obtained from labor offices and individual employers. Suitable alternatives are also sought.

Reasonable opportunity for resolving the problem of social adaptation is the use of released military property. Set for eviction, barracks areas are set to be given for business activities of the discharged from military service servicemen from the area. Such projects for the conversion of military bases have been developed jointly with the foundation Resource Center for the town of Simitli the village of Barshen, Sliven district, the regions of the town of Razgrad and the town of Dalgopol. There,servicemen who passed in the reserve should seek to attract investments, to exercise business that is missing in the market and to find their niche in local business development.

Attention should be paid that no Bulgarian bank offers or realizes any special credit program for servicemen who are about to leave the army. This means that neither the MoD nor the servicemen themselves have a partner bank.

Applicable is the agreement signed between the MoD and the Job Opportunities Through Business Support JOBS program to the UN. A campaign was conducted in this period, on which about 250 servicemen were trained. Some jobs and a few companies were created. Assistance was provided by the German Society for Technical Assistance - GTZ, and the German Chamber of Crafts in Koblenz, for the development of concrete projects for re-qualification and preparation of discharged servicemen for starting own business. 
Relevant measures were planned for young officers, leaving the army before the end of their first ten-year contract, namely:

- Opportunity for graduates with very good grades, who completed the four year course of education, to continue their education as cadets on a Master program in civil specialty;

- Opportunity for Master program graduates for recruitment on vacant positions, including captain's;

- Officers appointedon this temporary position, who wish to be discharged from military service can be discharged amicably without being liable to pay for their education.

Quantification of activities for the duration of the program from 2000 to 2004 is done through generalized and systematic quantitative indicators, presented in Table 1.

What makes impression, is that the analysis can be reduced only to that period, as this information is extremely scarce and such was not registered for the years after 2004. Therefore, we restricted ourselves within the shown parameters and the shown period. The lack of the necessary information base limited our opportunities for benchmarking. However, the fact that this is first attempt to determine the effectiveness of this kind of activity, such as social adaptation of the servicemen discharged from military service, cannot be denied (Terziev, 2018a, pp. 228-236; Stefanov, Terziev, Banabakova, 2018b, pp. 93-102; Stefanov, Terziev, Banabakova, 2018c, pp. 111-119; Terziev, Stefanov, Banabakova, 2018d, pp. 120-131; Terziev, Stefanov, Banabakova, 2018e, pp. 132-148; Terziev, 2018f, pp. 213-227; Terziev, 2018g, pp. 237-247; Terziev, 2018h, pp. 256-265; Terziev, 2018i, pp. 266-276; Terziev, Latyshev, Georgiev, 2018j, pp. 248-255; Glushkov, Simeonov, Georgiev, 2018k, pp. 88-92; Banabakova, Georgiev, 2017a, pp. 37-47).

Table 1. Indicators for assessment of program Social Adaptation and Economic Integration of Servicemen, Discharged from Military Service in the Civil Society

\begin{tabular}{|l|l|r|}
\hline N & INDICATORS & 2000-2004 \\
\hline 1. & & 23137 \\
\hline & $\begin{array}{l}\text { Visits inthe Center for Re-qualification and Social Adaptation } \\
\text { (CRSA)and the Regional Information Center (RIC) for } \\
\text { information and consultancy }\end{array}$ & \\
\hline 2. & & 10423 \\
\hline & Registered inCRSAand RIC - total: (A+B+C) & 232 \\
\hline & A. Registered servicemen at disposition & 151 \\
\hline & Officers & 9388 \\
\hline & Sergeants and sergeant majors & 5346 \\
\hline & B. Registered military reservists & 4042 \\
\hline & Officers & 803 \\
\hline & Sergeants and sergeant majors & 10191 \\
\hline & C. Registered members of servicemen families & 4593 \\
\hline & $\begin{array}{l}\text { Note: From the registered, those with right to start a job - } \\
\text { B+C }\end{array}$ & \\
\hline 3. & Directed to concrete jobs by the teams of the CRSA & \\
\hline & & \\
\hline
\end{tabular}




\begin{tabular}{|c|c|c|}
\hline \multicolumn{3}{|l|}{4.} \\
\hline & $\begin{array}{l}\text { Employedwith the direct assistance of the coordinators from } \\
\text { Foundation Resource Center (FRC) }(A+B)\end{array}$ & 2153 \\
\hline & $\begin{array}{l}\text { A. Employed, consulted by and having used the services of } \\
\text { the CRSA }\end{array}$ & 2023 \\
\hline & senior management level & 47 \\
\hline & medium management level & 177 \\
\hline & junior management level & 299 \\
\hline & executive positions & 843 \\
\hline & guards & 657 \\
\hline & B. Private entrepreneurs, having started own business & 130 \\
\hline \multicolumn{3}{|l|}{5.} \\
\hline & Employers with whom contact has been established & 1816 \\
\hline & $\begin{array}{l}\text { Towns and villages where contact with employers has been } \\
\text { established }\end{array}$ & 116 \\
\hline \multicolumn{3}{|l|}{6.} \\
\hline & Employers having declared job positions in CRSA & 970 \\
\hline & $\begin{array}{l}\text { Towns and villages where employers have declared job } \\
\text { positions }\end{array}$ & 88 \\
\hline \multicolumn{3}{|l|}{7.} \\
\hline & Job positions declared inCRSA & 4936 \\
\hline & senior management level & 73 \\
\hline & medium management level & 297 \\
\hline & junior management level & 323 \\
\hline & executive positions & 2265 \\
\hline & guards & 1968 \\
\hline
\end{tabular}




\begin{tabular}{|c|c|c|}
\hline & Towns and villages where job positions have been declared & 100 \\
\hline 8. & & \\
\hline & Vacant job positions declared inCRSAas of 29.02.2004 & 20 \\
\hline & $\begin{array}{l}\text { Towns and villages with vacant job positions as of } \\
\text { 29.02.2004 }\end{array}$ & 1 \\
\hline 9. & & \\
\hline & $\begin{array}{l}\text { Work contacts with employment bureaus and intermediary } \\
\text { institutions }\end{array}$ & 505 \\
\hline & $\begin{array}{l}\text { Towns and villages where contact has been established with } \\
\text { employment bureaus and recruitment agencies }\end{array}$ & 114 \\
\hline 10. & & \\
\hline & Towns and villages visited by the CRSA teams & 238 \\
\hline 11. & & \\
\hline & Passed in FRC on Ordinance No 4 & 5780 \\
\hline 12. & & \\
\hline & Provided legal consultations & 1708 \\
\hline 13. & & \\
\hline & Visited military units & 703 \\
\hline
\end{tabular}

The effectiveness of such kind of program for social adaptation of the formed qualitatively new risk group in the labor market is being realized for the first time in Bulgaria. The number of potential users is relatively high, approximately 70000 . At this point, the realization of such social projects is relatively new and different, and therefore neither legally nor legislatively provisioned. The discharged servicemen fall in a qualitatively new and different environment in society and the labor market. It is necessary to reflect the fact that the 
transformation of the national labor market is not yet completed, qualitative and quantitative differences in local and regional labor markets in the country are still observed.

It is the social institutions, such as municipal social assistance services and the territorial divisions of the Employment Agency - Employment bureaus and their branches, who are the ones to serve this new group formed in the labor market.

During this period, the Law on Protection Against Unemployment and Employment Promotion is in force, but it does not define this group of unemployed persons as a new one with different specific characteristics, but rather puts it in the context of the common terms and dependencies.

These and many other circumstances are the basis for the taken decisions, allowing this social project to be implemented with external and national funding, with the participation of representatives of nongovernmental organizations (NGO).

The number of the registered in the centers for social adaptation and RICs in the country, is 10,423 , which represents approximately $15 \%$ of the total number of potential users. Practically, this is a relatively small number of beneficiaries who seek opportunities through the program, without this meaning that they are direct beneficiaries. It can only be assumed that the rest of the falling in the group of the discharged from military service, seek the services of other institutions, offering this kind of assistance. Official statistics for these activities and registrations has not been collected in Bulgaria, neither by EA (Employment Agency), nor by the NSI.

The number of visits to professional counseling is 23,137 . This quantitative indicator cannot be deemed a criterion for achieving the appropriate result, moreover, only about $50 \%$ are directed through recruitment mediation for appointment to a particular vacant job position. The number of ones who started work as a result of information, counseling and labor mediation is about $20 \%$ or 2,023 people. Relatively high is the percentage of low-skill positions relating to executive positions and security activities, and the smallest is the share of those for highly qualified positions - only 47 or 2,1\% (Banabakova, Georgiev, 2018I, pp. 462-467; Terziev, 2017b, pp.517-528; Terziev, 2017c; Hristov, 2018m, pp. 277-282; Terziev, Nichev, 2017d, p.152; Terziev, Nichev, 2017e, pp.846-850; Terziev, Nichev, 2017f, p.164; Terziev, Nichev, 2017g, pp.915-919; Terziev, Madanski, Georgiev, 2017h, pp.743-747; Terziev, Madanski, Georgiev, 2017i, pp.748-753; Terziev, Nichev, Stoyanov, Georgiev, 2017j, pp.690-694; Terziev, Latyshev, Georgiev, 2017k, pp.754-772; Terziev, Nikolay, Bogdanov, 2017l, pp.671-677; Terziev, Madanski, Kanev, 2017m, pp.1331-1346; Terziev, Madanski, Kanev, 2017n, pp.1355-1372; Terziev, Madanski, Kanev, 2017o, pp.1380-1393; Terziev, Madanski, Kanev, 2017p, pp.396-415; Terziev, 2017q, pp.641-653; Terziev, Nichev, 2017r, pp.627-630; Terziev, Madanski, Kanev, 2017s, pp.575-594; Terziev, 2017t, pp.22-28; Terziev, Nichev, 2017u, pp.646658; Terziev, Nichev, 2017v, pp.659-670; Terziev, Madanski, 2017w, pp.610-625; Terziev, Madanski, 2017x, pp.917-937).

\section{CONCLUSION}

Considering that experience, gained in the implementation of such a national project, which on the one hand aims to successfully adapt discharged from military service servicemen, and on the other hand - to use the standardfor the labor market tools, is not quite successful. Naturally, it is necessary quantitative and qualitative criteria to be derived, which to make it possible to give clear and precise social and economic assessment of this type of endeavor.

Here the weakness can be defined in several key areas:

- Lack of theoretical and practical experience in the preparation, implementation and evaluation of this type of national programs and projects with a relatively large number of users;

- Lack of unified and coordinated regulatory framework that governs the inter-institutional cooperation, as well as detailed mechanism of implementation of the entire program and related activities;

- Absence of sufficient and well-trained specialists and professional consultants to assist the target group;

- Absence of assessment of the respective competences of the servicemen leaving Bulgarian Army at the output of the system, as well as assessment of future needs for acquiring new and qualitatively different knowledge, skills and experience;

- Specific needs in carrying out labor mediation in the primary labor market, as well as a clear need for the relevant activities in support of this process;

- Process of validating the received in the military university or school knowledge and their future viability 
under the new conditions;

- Occurrence of specific medical and psychological problems in the realizing of the adaptation process.

Knowing the weaknesses of the practical realization of the program Social Adaptation and Economic Integration of Discharged Military Staff from the Military Forces into the Civil Society, allows our scientific study to focus on the search for strategic solutions to increase the efficiency of this process by creating a comprehensive social pedagogical educational approach to the problem of social adaptation of servicemen, released from military service on the basis of well grounded, practice-oriented model of organization of the process of social adaptation.

\section{REFERENCE LIST}

Terziev, Venelin. (2018a). Building a model of social and pshychological adaptation. // ADVED 2018-4th International Conference on Advances in Education and Social Sciences Abstracts \& Proceedings, 1517 October 2018- Istanbul, Turkey, International Organization Center of Academic Research, www.ocerints.org, Istanbul, Turkey, 2018, pp. 228-236, ISBN: 978-605-82433-4-7.

Stefanov, S., Terziev, V., Banabakova, V. (2018b). The undertsanding of security in the postmodern society. // ADVED 2018- 4th International Conference on Advances in Education and Social Sciences Abstracts \& Proceedings, 15-17 October 2018- Istanbul, Turkey, International Organization Center of Academic Research, www.ocerints.org, Istanbul, Turkey, 2018, pp. 93-102, ISBN: 978-605-82433-4-7.

Stefanov, S., Terziev, V., Banabakova, V. (2018c). Levels of security and postmodern society. // ADVED 2018- 4th International Conference on Advances in Education and Social Sciences Abstracts \& Proceedings, 15-17 October 2018- Istanbul, Turkey, International Organization Center of Academic Research, www.ocerints.org, Istanbul, Turkey, 2018, pp. 111-119, ISBN: 978-605-82433-4-7.

Terziev, V., Stefanov, S., Banabakova, V. (2018d). Implementattion of the common european security and defence policy in the context of its military aspect. // ADVED 2018- 4th International Conference on Advances in Education and Social Sciences Abstracts \& Proceedings, 15-17 October 2018- Istanbul, Turkey, International Organization Center of Academic Research, www.ocerints.org, Istanbul, Turkey, 2018, pp. 120-131, ISBN: 978-605-82433-4-7.

Terziev, V., Stefanov, S., Banabakova, V. (2018e). Common european security and defence policy. // ADVED 2018- 4th International Conference on Advances in Education and Social Sciences Abstracts \& Proceedings, 15-17 October 2018- Istanbul, Turkey, International Organization Center of Academic Research, www.ocerints.org, Istanbul, Turkey, 2018, pp. 132-148, ISBN: 978-605-82433-4-7.

Terziev, Venelin. (2018f). Bulgarian experience in the development of social adaptation of military personnel, discharged from military service and their families. // ADVED 2018- 4th International Conference on Advances in Education and Social Sciences Abstracts \& Proceedings, 15-17 October 2018- Istanbul, Turkey, International Organization Center of Academic Research, www.ocerints.org, Istanbul, Turkey, 2018, pp. 213-227, ISBN: 978-605-82433-4-7.

Terziev, Venelin. (2018g). Opportunities of aplication of a competence-based approach in social adaptation of militaries discharged of service. // ADVED 2018- 4th International Conference on Advances in Education and Social Sciences Abstracts \& Proceedings, 15-17 October 2018- Istanbul, Turkey, International Organization Center of Academic Research, www.ocerints.org, Istanbul, Turkey, 2018, pp. 237-247, ISBN: 978-605-82433-4-7.

Terziev, Venelin. (2018h). Possible aspects of occupational and psychological adaptation of the military, discharged from military service and their families to a new activity life cycle. // ADVED 2018- 4th International Conference on Advances in Education and Social Sciences Abstracts \& Proceedings, 1517 October 2018- Istanbul, Turkey, International Organization Center of Academic Research, www.ocerints.org, Istanbul, Turkey, 2018, pp. 256-265, ISBN: 978-605-82433-4-7.

Terziev, Venelin. (2018i). Realities of implementing the social adaptation process of military personnel, discharged form service in Bulgaria. // ADVED 2018- 4th International Conference on Advances in Education and Social Sciences Abstracts \& Proceedings, 15-17 October 2018- Istanbul, Turkey, International Organization Center of Academic Research, www.ocerints.org, Istanbul, Turkey, 2018, pp. 266-276, ISBN: 978-605-82433-4-7. 
Terziev, V., Latyshev, O., Georgiev, M. (2018j). The warehousing as an element of army logistics system in conditions of arctics (from experience of bulgarianrussian cooperation). // ADVED 2018- 4th International Conference on Advances in Education and Social Sciences Abstracts \& Proceedings, 1517 October 2018- Istanbul, Turkey, International Organization Center of Academic Research, www.ocerints.org, Istanbul, Turkey, 2018, pp. 248-255, ISBN: 978-605-82433-4-7.

Glushkov, P., Simeonov, S., Georgiev, M. (2018k). Method of determination of the diurnal energy consumption of the cadets from the Vasil Levski National Military university. ADVED 2018- 4th International Conference on Advances in Education and Social Sciences Abstracts \& Proceedings, 1517 October 2018- Istanbul, Turkey, International Organization Center of Academic Research, www.ocerints.org, Istanbul, Turkey, 2018, pp. 88-92, ISBN: 978-605-82433-4-7.

Banabakova, V., Georgiev, M. (2017a). Problems and perspectives in Military professional education and realization of cadets in Bulgaria. // Journal of Innovations and Sustainability, Innovations and Sustainability Academy. 3, 2017, N 4, pp. 37-47, ISSN 2367-8127 (CD-ROM), ISSN 2367-8151 (online).

Banabakova, V., Georgiev, M. (2018I). Military professional forming of the cadets at Vasil Levski National Military University. // Proceedings of INTCESS2018- 5th International Conference on Education and Social Sciences 5-7 February 2018- Istanbul, Turkey, International Organization Center of Academic Research, www.ocerints.org, Istanbul, Turkey, 2018, pp. 462-467, ISBN : 978-605-82433-2-3.

Terziev, Venelin. (2017b). Opportunities and trends in the development and the improvement processes in the Bulgarian military educational system. // 3rd Central \& Eastern European LUMEN International Conference, New Approaches in Social and Humanistic Sciences NASHS 2017, Chisinau, Republic of Moldova, June 8-10, 2017, 2018, pp.517-528, ISSN (print): 2601 - 2510, ISSN (on-line): 2601 2529, ISSN-L: 2601 - 2510, ISBN: 978-1-910129-15-9.

Terziev, Venelin. (2017c). Opportunities for improving the efficiencyof the socialadaptation of servicemen discharged from military service in Bulgaria. // Catalogue of the scientific, educational and methodical literature presented by authors at the I-XXXIV All-Russian book exhibitions held by Academy of Natural History, Exposition on the Frankfurter Buchmesse 2017, XXVII, Moskow, Academy of Natural History, 2017.

Hristov, Neno. (2018m). European intervention initiative vs common European army. ADVED 2018- 4th International Conference on Advances in Education and Social Sciences Abstracts \& Proceedings, 1517 October 2018- Istanbul, Turkey, International Organization Center of Academic Research, www.ocerints.org, Istanbul, Turkey, 2018, pp. 277-282, ISBN: 978-605-82433-4-7.

Terziev, V., Nichev, N. (2017d). Research on the management skills and abilities acquired in the military education system. // CBU International Conference Book of Abstracts March 22-24, Prague, Czech Republic, Innovations in Science and Education, 2017, ISBN 978-80-88042-09-9, p.152.

Terziev, V., Nichev, N. (2017e). Research on the management skills and abilities acquired in the military education system. // CBU International Conference Proceedings 2017, March 22-24, Prague, Czech Republic, Innovations in Science and Education, 2017, SSN 1805-997X (Print), ISBN 978-80-8804207-5 (Print edition), pp.846-850.

Terziev, V., Nichev, N. (2017f). Developing the readiness for the organizational activity of the cadets. // CBU International Conference Book of Abstracts March 22-24, Prague, Czech Republic, Innovations in Science and Education, ISBN 978-80-88042-09-9, p.164.

Terziev, V., Nichev, N. (2017g). Developing the readiness for the organizational activity of the cadets. // CBU International Conference Proceedings 2017, March 22-24, Prague, Czech Republic, Innovations in Science and Education, 2017, SSN 1805-997X (Print), ISBN 978-80-88042-07-5 (Print edition), pp.915-919.

Terziev, V., Madanski, V., Georgiev, M. (2017h). Offset implementation impact on technology transfer in Bulgaria. // Proceedings of ADVED 2017- 3rd International Conference on Advances in Education and Social Sciences 9-11 October 2017- Istanbul, Turkey, 2017, ISBN: 978-605-82433-0-9, pp.743-747.

Terziev, V., Madanski, V., Georgiev, M. (2017i). Offset as an economic operation and a trade practice. // Proceedings of ADVED 2017- 3rd International Conference on Advances in Education and Social Sciences 9-11 October 2017- Istanbul, Turkey, 2017, ISBN: 978-605-82433-0-9, pp.748-753.

Terziev, V., Nichev, N., Stoyanov, E., Georgiev, M. (2017j). A general principle of the development process 
of balanced scorecards as an instrument of control. // Proceedings of ADVED 2017- 3rd International Conference on Advances in Education and Social Sciences 9-11 October 2017- Istanbul, Turkey, 2017, ISBN: 978-605-82433-0-9, pp.690-694.

Terziev, V., Latyshev, O., Georgiev, M. (2017k). Building competencies for social work through continuing vocational training. // Proceedings of ADVED 2017- 3rd International Conference on Advances in Education and Social Sciences 9-11 October 2017- Istanbul, Turkey, 2017, ISBN: 978-605-82433-0-9, pp.754-772.

Terziev, V., Nikolay, N., Bogdanov, P. (2017I). Comparative analysis of the formation of military professional skills in the cadets to be trained in logistics specializations. // Proceedings of ADVED 2017- 3rd International Conference on Advances in Education and Social Sciences 9-11 October 2017- Istanbul, Turkey, 2017, ISBN: 978-605-82433-0-9, pp.671-677.

Terziev, V., Madanski, V. Kanev, D. (2017m). Entry opportunities in the Bulgarian military-educational system. // Sport, Education and Society, Taylor \& Francis, 22, 2017, N 8(2), Source Normalized Impact per Paper (SNIP): 1.459 SCImago Journal Rank (SJR): 1.005 Impact factor: 1.269 Ranking: 60/230 (Education \& Educational Research), 20/44 (Hospitality, Leisure, Sport and Tourism), 51/82 (Sport Sciences), Print ISSN: 1357-3322 Online ISSN: 1470-1243, pp.1331-1346.

Terziev, V., Madanski, V., Kanev, D. (2017n). Condition and capabilities of the military-educational system of the Republic of Bulgaria. // Sport, Education and Society, Taylor \& Francis, 22, 2017, N 8(2), Source Normalized Impact per Paper (SNIP): 1.459 SCImago Journal Rank (SJR): 1.005 Impact factor: 1.269 Ranking: 60/230 (Education \& Educational Research), 20/44 (Hospitality, Leisure, Sport and Tourism), 51/82 (Sport Sciences), Print ISSN: 1357-3322 Online ISSN: 1470-1243, pp.1355-1372.

Terziev, V., Madanski, V., Kanev, D. (2017o). Directions for improvement of the military-educational system and its contribution for strengthening national security and the defence of the country. // Sport, Education and Society, Taylor \& Francis, 22, 2017, N 8(2), Source Normalized Impact per Paper (SNIP): 1.459 SCImago Journal Rank (SJR): 1.005 Impact factor: 1.269 Ranking: 60/230 (Education \& Educational Research), 20/44 (Hospitality, Leisure, Sport and Tourism), 51/82 (Sport Sciences), Print ISSN: 1357-3322 Online ISSN: 1470-1243, pp.1380-1393.

Terziev, V., Madanski, V., Kanev, D. (2017p). Entry opportunities in the bulgarian military-educational system and ensuring of civil rights. // IJAEDU- International E-Journal of Advances in Education, 3, 2017, N 8 , e-ISSN:2411-1821, pp.396-415.

Terziev, Venelin. (2017q). The needs of continuing vocational training of social work specialists providing social services. // Proceedings of SOCIOINT 2017- 4th International Conference on Education, Social Sciences and Humanities 10-12 July 2017- Dubai, UAE, 2017, ISBN: 978-605-82433-1-6, pp.641-653.

Terziev, V., Nichev, N. (2017r). Analysis of the environment for military educational system functioning and its impact on the preparation of cadets for military professional activities in the republic of Bulgaria. // Proceedings of SOCIOINT 2017- 4th International Conference on Education, Social Sciences and Humanities 10-12 July 2017- Dubai, UAE, 2017, ISBN: 978-605-82433-1-6, pp.627-630.

Terziev, V., Madanski, V., Kanev, D. (2017s). Entry opportunities in the bulgarian military-educational system and ensuring of civil rights. // Proceedings of SOCIOINT 2017- 4th International Conference on Education, Social Sciences and Humanities 10-12 July 2017- Dubai, UAE, 2017, ISBN: 978-60582433-1-6, pp.575-594.

Terziev, Venelin. (2017t). National security of the republic of Bulgaria. // International Journal of Management and Applied Science, 3, 2017, N 4, ISSN: 2394-7926, pp.22-28.

Terziev, V., Nichev, N. (2017u). Research of the value orientation and structural peculiarities of management activitiesofcadets in the course of military professional training. // Proceedings of the VII International Academic Congress „Fundamental and Applied Studies in EU and CIS Countries” (United Kingdom, Cambridge, England, 26-28 February 2017), Cambridge University Press, 7, 2017, ISBN: 978-0-87583597-4, pp.646-658, Source Normalized Impact per Paper (SNIP): 5.192 SCImago Journal Rank (SJR): 5.186 Impact factor: 7.549 .

Terziev, V., Nichev, N. (2017v). Research of the motivation for management activities of cadets in the course of their military professional training. // Proceedings of the VII International Academic Congress „Fundamental and Applied Studies in EU and CIS Countries” (United Kingdom, Cambridge, England, 26-28 February 2017), Cambridge University Press, 7, 2017, ISBN: 978-0-875-83597-4, pp.659-670, Source Normalized Impact per Paper (SNIP): 5.192 SCImago Journal Rank (SJR): 5.186 Impact 
factor: 7.549 .

Terziev, V., Madanski, V. (2017w). Guidelines for development of military education system in Bulgaria. // Proceedings of the VII International Academic Congress "Fundamental and Applied Studies in EU and CIS Countries" (United Kingdom, Cambridge, England, 26-28 February 2017), Cambridge University Press, ISBN: 978-0-875-83597-4, 7, 2017, pp.610-625, Source Normalized Impact per Paper (SNIP): 5.192 SCImago Journal Rank (SJR): 5.186 Impact factor: 7.549.

Terziev, V., Madanski, V. (2017x). Development of military education system in Bulgaria. // American Journal of Education, The University of Chicago Press, 2017, 123, 2017, N 4 (2), ISSN: 0195-6744, pp.917937, Source Normalized Impact per Paper (SNIP): 1.653, SCImago Journal Rank (SJR): 2.243. 